Creative Commons User License: CC BY-NC-ND

Abstracted by: EBSCOhost, Electronic Journals Service (EJS), Google Scholar, Journal Seek, Scientific Commons,

Food and Agricultural Organization (FAO), CABI and Scopus

http://eoi.citefactor.org/10.11226/v24i3
Journal of Agricultural Extension

Vol. 24 (3) July, 2020

ISSN(e): 24086851; ISSN(Print); 1119944X

http://journal.aesonnigeria.org

http://www.ajol.info/index.php/iae

Email: editorinchief@aesonnigeria.org

\title{
Consumers' Perception of Dried Onion and Okra Using Load Adaptive Drying Technology in Nsukka Urban, Nigeria \\ https://dx.doi.org/10.4314/jae.v24i3.11
}

\section{Anoliefo, Edward}

Department of Electronic Engineering,

University of Nigeria, Nsukka.

Email: edward.anoliefo@unn.edu.ng

\section{Chah, Jane}

Department of Agricultural Extension, University of Nigeria, Nsukka.

Email: jane.chah@unn.edu.ng

Corresponding author.

\author{
Abbah, Oliver \\ Department of Human Kinetics and Health Education, \\ University of Nigeria, Nsukka. \\ Email: oliver.abbah@unn.edu.ng \\ Corresponding author.
}

\begin{abstract}
The study determined consumers' perception of onions and okra dried with load adaptive drying technology (LADT). Random sampling technique was used to select equal number of adult male, adult female, young men and young women as respondents. Structured interview schedule was used to elicit data from the respondents, while, percentage, mean score and multiple linear regression were used to analyze the data. All the respondents had a favourable perception of Onions and Okra dried with LADT. Willingness to use was dependent on taste, aroma and texture in the case of Onions. For Okra, willingness to use was dependent on colour and texture. There was a general willingness to use the products dried with the load adaptive technology, it was, therefore, necessary for the Centre for Lion Gadgets and Technologies, University of Nigeria, Nsukka (CLGT) to collaborate with agricultural extension agencies to disseminate the product to farmers and processors for use.
\end{abstract}

Keywords: photovoltaic, dryer, load adaptive, consumers, perception, okra, onion

\section{Introduction}

Globally, food waste/loss is a major challenge with high financial, ethical and environmental cost especially among rural farmers. One of the reasons for this problem is the challenge associated with drying and drying technologies. Sun drying has been found to be highly inefficient (Hussein, Usman, and Filli, 2016). Electrical drying is one of such alternatives but its cost intensiveness makes it unattractive to 
Creative Commons User License: CC BY-NC-ND

Abstracted by: EBSCOhost, Electronic Journals Service (EJS), Google Scholar, Journal Seek, Scientific Commons,

Food and Agricultural Organization (FAO), CABI and Scopus

http://eoi.citefactor.org/10.11226/v24i3
Journal of Agricultural Extension

Vol. 24 (3) July, 2020

ISSN(e): 24086851; ISSN(Print); 1119944X

http://journal.aesonnigeria.org

http://www.ajol.info/index.php/iae

Email: editorinchief@aesonnigeria.org

low income users (Nwakuba,Okafioir, Okore and Okoafor,2020). Recently, research efforts have focused on solar thermal dryers as a way of reducing energy cost of drying. The basic problem of solar thermal dryers is the unpredictable variability of the sun which is the primary heat source. During extended low temperature regimes, drying is sluggish allowing internal agents (especially enzymatic activities) (Ma, Qing-JieSun, Man and Ke-Xue, 2020) and external agents (microbial activities) (Lianou, Panagou and Nychas, 2016) to reduce the quality of dried products. Conversely, extended exposure to high temperature leads to reduction in sensory and nutritional properties of the crop (Essohouna Takougnadi,Tcha-Esso Tchamye Borozo, and Ouézou Yaovi Azouma, 2020,). Effort to solve this problem has often resulted to bulky systems that are too cumbersome for domestic adoption. Hence, a primary survey undertaken by the Centre for Lion Gadgets and Technologies, University of Nigeria, Nsukka (CLGT, UNN) revealed that less than $10 \%$ of people within Enugu State, Nigeria, adopted any of the solar thermal dryers.

In view of the above problems, a load adaptive, photovoltaic powered multi crop dryer was developed at the CFLGT, UNN. The dryer was designed to have photovoltaic (PV) module as the only source of power. A battery and charge controller were included to improve storage of excess solar radiation. Considering low cost, availability and ease of control, incandescent lamps were used as a heating source (Izquierdo-Gil, Barragán and Villaluenga, 2020). To enhance acceptability by households, and improve conservation of available radiant energy, the design and implementation of the dryer was based on a disused double cabin refrigerator. To further reduce transmission loss and improve seamless temperature control, both the dryer and collector were located within a single black painted chamber. A pulse width modulated fan was placed before the lamps for temperature distribution and enhancement of mass flow rate. The air velocity was set to $1.6 \mathrm{~m} / \mathrm{s}$ using pulse width modulation technique. With the aid of relay modules Arduino Mega microcontroller was used to control both the source power and temperature within the chamber.

A design diagram of the dryer indicating its major parts is shown in Figure 1. 
Creative Commons User License: CC BY-NC-ND

Abstracted by: EBSCOhost, Electronic Journals Service (EJS), Google Scholar, Journal Seek, Scientific Commons,

Food and Agricultural Organization (FAO), CABI and Scopus

http://eoi.citefactor.org/10.11226/v24i3
Journal of Agricultural Extension

Vol. 24 (3) July, 2020

ISSN(e): 24086851; ISSN(Print); 1119944X

http://journal.aesonnigeria.org

http://www.ajol.info/index.php/iae

Email: editorinchief@aesonnigeria.org

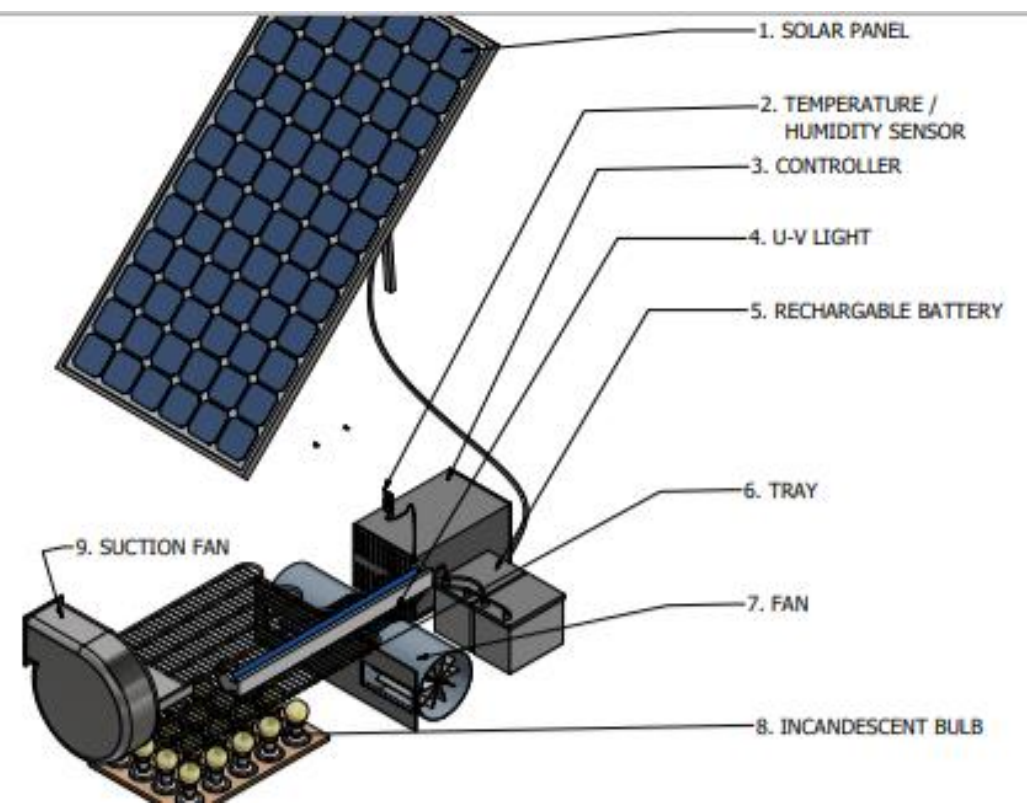

Figure 1: Basic components of the load adaptive dryer.

In Figure 2, a picture of the deployed dryer is shown

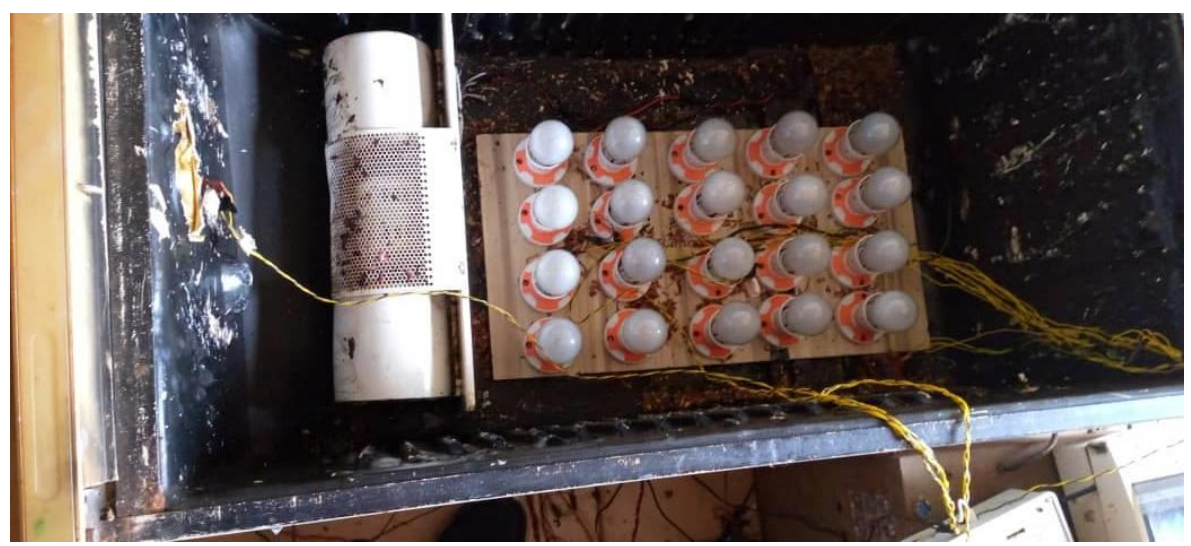

Figure 2: Picture load adaptive dryer.

After the deployment of two fully functional prototypes and their technical characterization, the dryers were used to dry Okra and Onions. Subsequently, a study of consumers' perception of onions and okra dried using the technology was undertaken. Perception can be described as the ability to recognize and identify the existence of all kinds of stimuli and then evaluate and give meanings to them (Qiong, 2017). The basic hypothesis is there is need for visual attention in order to properly bind features of an object (Wolfe, 2020). Consumer preference had been described 
Creative Commons User License: CC BY-NC-ND

Abstracted by: EBSCOhost, Electronic Journals Service (EJS), Google Scholar, Journal Seek, Scientific Commons,

Food and Agricultural Organization (FAO), CABI and Scopus
Journal of Agricultural Extension

Vol. 24 (3) July, 2020

ISSN(e): 24086851; ISSN(Print); 1119944X

http://journal.aesonnigeria.org

http://www.ajol.info/index.php/jae

Email: editorinchief@aesonnigeria.org

as consisting of a group of assumptions which permit a consumer to classify different types of products following levels of utility or holistic satisfaction or dissatisfaction of consuming particular goods or services (Isik and Yasar, 2015). In doing this, earlier studies have indicated that consumers usually display a certain ambivalent approach when exposed to products that are novel to them or ones they are unaccustomed to. In the field of food and beverages, some authors have described this in terms of Paul Rozin's omnivore's dilemma (Pollan, 2020). The dilemma is described in terms of the fact that human beings have combination of curiosity and fear towards unfamiliar food products. In view of this, consumers' may prefer food which are novel and which pose no fear to their well-being. In other words, the theory holds that consumers would more likely go for food that has right amount of novelty but elicits enough familiarity as not to induce fear.

There have also been theories around optimal arousal. Conspicuous among optimal arousal theories is the collative-motivational model proposed by Berlyne (1966). Collative properties may be referred to as those things that catching attention significantly affects the arousal level of an individual towards the food. Such properties also tend to primordially describe a person's interest and perception of an object. He used it to account for varying aesthetic appreciation of food. Berlyne's model proposes that arousal potential takes the shape of an inverted $U$. In this model a stimulus with a moderate arousal potential will be given preference. Fibri and Frøst (2019) demonstrated that studies on consumers' perception on food ought to focus on collative properties of the food under investigation. Similarly, the model has been used to account for sensory preferences among consumers (Symmank, 2019). In studying sensory preferences, the flavour of a given food is considered key component of the consumer's judgement on the quality of the product. It is also considered a single most determinant indicator of whether the consumer will continue purchasing the product (Salvador, 2014). In this study, taste, aroma, colour and extent of dryness of the Onions dried using the load adaptive drying technology are considered important indicators whether a customer would like to continue using the onions dried with the load adaptive dryer. Similarly, aroma, taste, colour and texture of prepared okra soup are considered important indicators of whether users would likely continue cooking with the okra dried with the load adaptive drying technology. The purpose of this work was to determine consumers' perception of Onions and Okra dried using load adaptive drying technology.

\section{Methodology}

\section{Drying Method}

Prior to drying, the initial moisture content of both Onions and Okra were determined using methods specified in Latimer, (2012). Using M-Metlar (M311L), an analytical balance with a specified resolution of $0.01 \mathrm{~g}, 800 \mathrm{~g}$ of both products were successively weighed and loaded into the drying tray.

Figure 3 shows the operational flowchart of the dryer. At start up, the user was requested to supply the type and mass of product loaded into the system. The 
Creative Commons User License: CC BY-NC-ND

Abstracted by: EBSCOhost, Electronic Journals Service (EJS), Google Scholar, Journal Seek, Scientific Commons,

Food and Agricultural Organization (FAO), CABI and Scopus

http://eoi.citefactor.org/10.11226/v24i3
Journal of Agricultural Extension

Vol. 24 (3) July, 2020

ISSN(e): 24086851; ISSN(Print); 1119944X

http://journal.aesonnigeria.org

http://www.ajol.info/index.php/iae

Email: editorinchief@aesonnigeria.org

system then calculated the energy cost for fast, medium and slow drying. A choice for slow drying was made on account of higher efficiency associated with it.

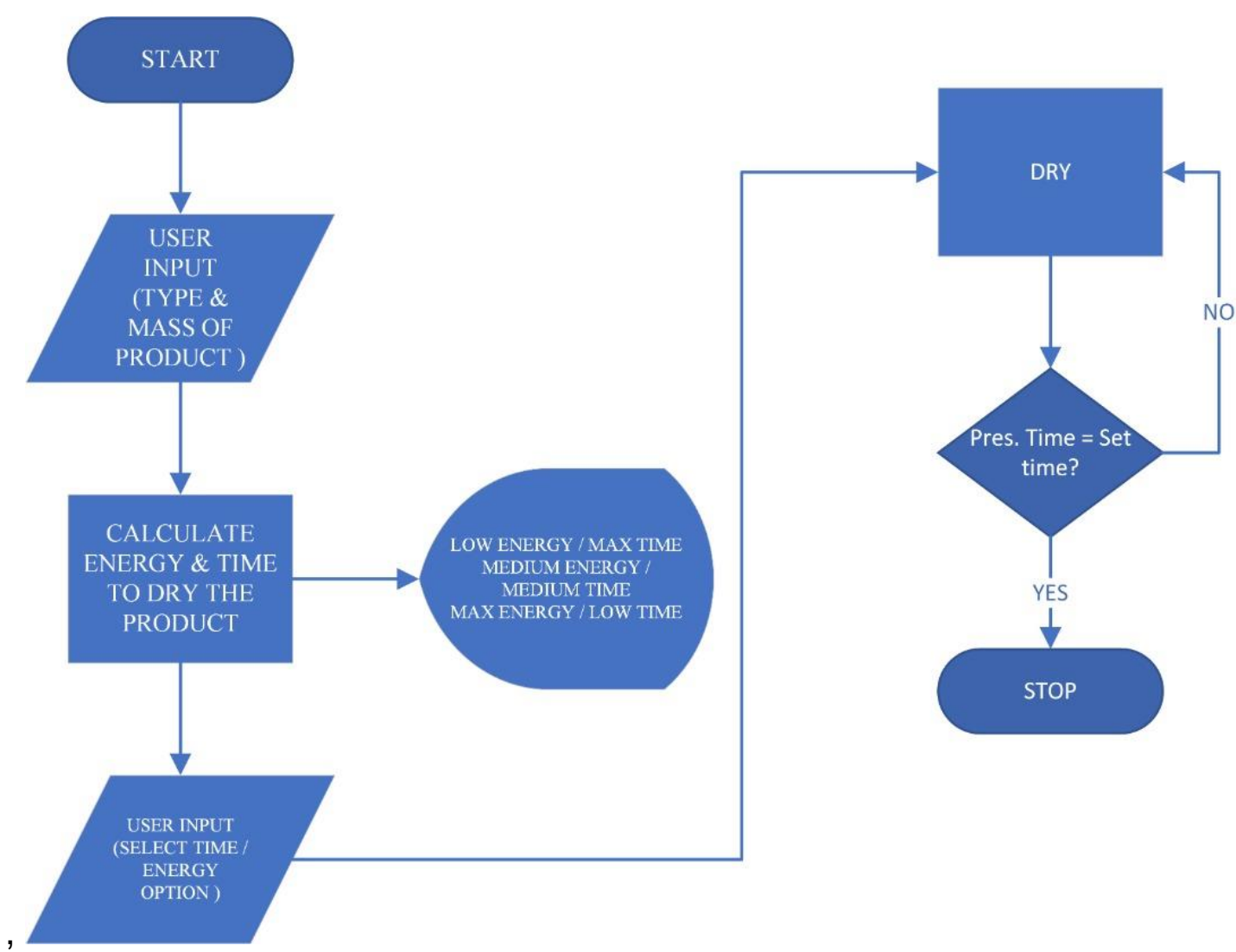

Figure 3: Operational flowchart of the dryer.

As the drying proceeded, instantaneous mass of each product was measured at 10 minutes' intervals. The percentage mass change over time was then calculated using equation (1).

$\%$ mass change $=\left(\frac{\text { instantenous mass }}{\text { initial mass }}\right) * 100$

The plot of percentage mass over time was then used to generate a polynomial equation whose solution gave the time to attain minimum mass reduction for any other mass of the products dried under similar condition.

To express the mass reduction in terms of moisture content equation (2) was used.

Present moisture content $\left(M_{p}\right)=\frac{m_{p r i} * M_{i}-\left(m_{p r i}-m_{p r e}\right)}{m_{p r e}}$

Where $m_{\text {pri }}=$ initial mass of product, $\left(m_{\text {pre }}\right)=$ present mass of product, $M_{i}=$ initial Moisture content). 
Creative Commons User License: CC BY-NC-ND

Abstracted by: EBSCOhost, Electronic Journals Service (EJS), Google Scholar, Journal Seek, Scientific Commons,

Food and Agricultural Organization (FAO), CABI and Scopus
Journal of Agricultural Extension

Vol. 24 (3) July, 2020

ISSN(e): 24086851; ISSN(Print); 1119944X

http://journal.aesonnigeria.org

http://www.ajol.info/index.php/iae

Email: editorinchief@aesonnigeria.org

Moisture ratio is an important indicator of the drying rate (Rasool Sadin, Gholamreza Chegini and Mehdi Khodadadi, 2017). It is defined it as

$M R=\frac{m_{t}-m_{e}}{m_{i}-m_{e}}$

where, $m_{i}=$ initial moisture content of the tomato slices,

$m_{e}=$ equilibrium moisture, and $m_{t}=$ moisture content at each time.

This study was conducted within Nsukka Urban, Enugu State, Nigeria. Nsukka is located within longitude $6^{\circ} 51^{\prime} 28.19^{\prime \prime} \mathrm{N}$ and latitude $7^{\circ} 23^{\prime} 44.77^{\prime \prime} \mathrm{E}$. Nsukka is a cosmopolitan, university town having a mix of people from different backgrounds who are mostly farmers. Nsukka has five major socio-political divisions including Odenigwe, Odenigbo, Ugwunkwo, Ugwuoye and Barracks. Okra is commonly cultivated, while Onion is purchased from the northern states of Nigeria. Both crops are widely consumed by the residence of Nsukka urban. One common problem of producers and consumers is the seasonality of the products which strongly impacts on the cost. They were used to traditionally dried okra, called ukpo okwuru. The majority were, however, not exposed to dry Onions.

Onions and okra consumers in Nsukka urban made up the population for the study. Random sampling technique was used to select respondents for the study. All the socio-political divisions (Odenigwe, Odenigbo, Ugwunkwo, Ugwuoye and Barracks) were used for the study. Fifty each of adult men, adult women, young men and young women were selected. This gave a total of 250 respondents. Structured interview schedule was used to elicit data from the respondents. The instrument was validated by experts from the Departments of Agricultural Extension and Food Science and Technology, University of Nigeria, Nsukka.

Both Okra and Onions were dried to $10 \%$ moisture content. The dried Onions were presented as crispy snack. The Okra was used to prepare okra soup. Sample consumers were subsequently served the prepared soup before the administration of the interview.

Consumer preferences for the products dried using load adaptive drying techniques were measured on a 5 point Likert-type scale of to a very great extent-5, to a great extent- 4 , to an extent-3, to a little extent- 2 and to a very little extent- 1 . The cut-off point was obtained by adding the weighted scores $(5+4+3+2+1 / 5)$ and divided by 5 to obtain 3 . Any mean score equal to or above 3 was considered a favourable perception while mean score less than 3 was considered unfavourable perception of the dried products. There were a total of five statements for each product. Each respondent was asked to evaluate the taste, aroma, colour, texture of the two samples. Their acceptance of the products was measured by soliciting the respondent's intention to use the dry products. Consumers' willingness to use the products dried using the load adaptive drying technology was also considered as dependent on consumers' perception of the colour, taste, aroma and texture/level of dryness of dried products. Accordingly, a multiple linear regression was conducted with consumers' perception of the colour, taste, aroma and texture of dried products as independent variables and willingness to use as dependent variable. Mean score, 
Creative Commons User License: CC BY-NC-ND

Abstracted by: EBSCOhost, Electronic Journals Service (EJS), Google Scholar, Journal Seek, Scientific Commons,

Food and Agricultural Organization (FAO), CABI and Scopus

http://eoi.citefactor.org/10.11226/v24i3
Journal of Agricultural Extension

Vol. 24 (3) July, 2020

ISSN(e): 24086851; ISSN(Print); 1119944X

http://journal.aesonnigeria.org

http://www.ajol.info/index.php/jae

Email: editorinchief@aesonnigeria.org

and multiple regression analysis were used to analyse the data. Descriptive and regression analyses were done using Xrealstats an add-in to the excel package. The model equation was of the form:

$=\beta_{0}+\beta_{1} x_{1}+\beta_{2} x_{2}+\beta_{2} x_{2}+\beta_{2} x_{2}+\varepsilon$

Where:

$Y=$ willingness to use

$0=$ intercept

$\mathrm{x}_{1}=$ Taste

$\mathrm{x}_{2}=$ Colour

$\mathrm{x}_{3}=$ Aroma

$\mathrm{x}_{4}=$ Texture/extent of dryness

All analyses were done at $5 \%$ level of probability.

\section{Results and Discussion}

\section{Drying Pattern of Onions and Okra}

The mass reduction of onions and okra being dried measured over 10 minutes interval were used to calculate their respective moisture ratios over time using equations 1-3. The graph is given in Figure 5.

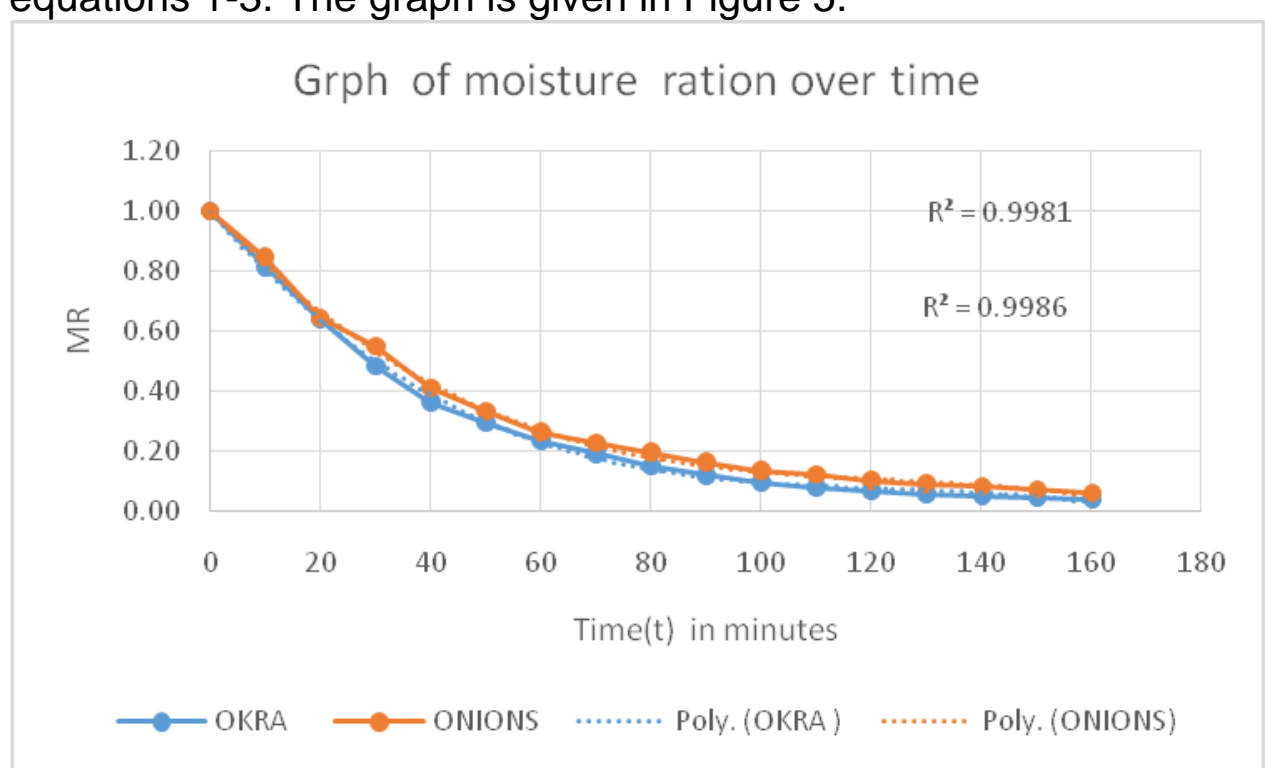

Figure 5: Graph of moisture ratio over time

The model equation for onion is given in equation (5).

$M R=-4 E^{-07} t^{3}+0.0002 t^{2}-0.0199 t+1.007+\varepsilon$

$\varepsilon$ is defined as the random error associated with the process.

The model equation of okra is given in equation (6).

$M R=-5 E^{-07} t^{3}+0.0002 t^{2}-0.0212+1.007+\varepsilon$

The $R^{2}$ of the two polynomials shown in equation 5 and 6 is $0.998 x$. This indicates that the equation of moisture ratio as a function of time could be reliably used in predicting both the drying time and the moisture content at any given time. For this to hold, however, the onions must be thinly cut and spread on the dryer with care so 
Creative Commons User License: CC BY-NC-ND

Abstracted by: EBSCOhost, Electronic Journals Service (EJS), Google Scholar, Journal Seek, Scientific Commons,

Food and Agricultural Organization (FAO), CABI and Scopus

http://eoi.citefactor.org/10.11226/v24i3
Journal of Agricultural Extension

Vol. 24 (3) July, 2020

ISSN(e): 24086851; ISSN(Print); 1119944X

http://journal.aesonnigeria.org

http://www.ajol.info/index.php/iae

Email: editorinchief@aesonnigeria.org

that none is on top of the other. This finding is in general agreement with the result obtained in similar works by other researchers. Gouda, Ramachandra, and Nidoni (2014) had studied the moisture ratio over time of onions dried using different methods. In their work the minimum reported drying time was nine hours. In drying onions using this method, as shown in figure 5 the onion dried in less than three hours. This also resulted to better drying curve. Nwakuba, Chukwuezie and Osuchukwu (2017) have also researched on the impact of dry varying air velocity on onion dried using hybrid dryer. Their result drying at $1.5 \mathrm{~m} / \mathrm{s}$ is in agreement with the result of this study. This reinforces the fact that drying at constant power and optimal air velocity greatly improve drying curve.

\section{Consumers' Perception of Dried Products}

Table 1 shows the mean and standard deviation scores for consumers' perceptions of the products. The mean score of over 3.69 for every perception indicator under consideration shows that the general perception of the dried product across classes was favourable. The average of absolute difference in the mean scores of adult male and female was 0.4075 . This means that families were very likely to use onions and okra dried using the load adaptive drying technology. The expectation is that with widespread adoption of this drying technology, spoilages and wastages associated with onions and okra at boom periods will be reduced.

There was an apparent trend in the responses to the indicator in respect of both onions and okra. It can be surmised that the consistency in trend points to the ability of the dryer to efficiently dry onions and okra. Further examination of Tables 1 and 2 shows that beside the uniform trend in the general mean score, there is also a general reduction in the quantitative scores of the indicators with respect to okra. The average of the general mean score for onions was 3.97, while that of okra was 3.82. Regarding the lower performance of okra on perception indicators, it is demonstrable that this is not as a result of differences in the quality of the dried product. It is more largely as a result of greater interest generated by the novelty of successfully drying of onions. This position is in agreement with the findings of Sunga, Vanmanb and Hartleyc(2019) that undertaking to resolve consumers paradoxical tendency to enthralled by both novelty and familiarity. They concluded that familiarity make people to like a product while novelty leads to heightened interest. 
Creative Commons User License: CC BY-NC-ND

Abstracted by: EBSCOhost, Electronic Journals Service (EJS), Google Scholar, Journal Seek, Scientific Commons,

Food and Agricultural Organization (FAO), CABI and Scopus

http://eoi.citefactor.org/10.11226/v24i3
Journal of Agricultural Extension

Vol. 24 (3) July, 2020

ISSN(e): 24086851; ISSN(Print); 1119944X

http://journal.aesonnigeria.org

http://www.ajol.info/index.php/jae

Email: editorinchief@aesonnigeria.org

Table 1: Consumers' perception of dried products

\begin{tabular}{|c|c|c|c|c|c|c|c|c|c|c|}
\hline \multirow[t]{2}{*}{ Characteristics } & \multicolumn{2}{|c|}{ General } & \multicolumn{2}{|c|}{$\begin{array}{l}\text { Adult } \\
\text { male }\end{array}$} & \multicolumn{2}{|c|}{ Adult female } & \multicolumn{2}{|c|}{ Young male } & \multicolumn{2}{|c|}{ Young female } \\
\hline & Mean & SD & Mean & SD & Mean & SD & Mean & SD & Mean & SD \\
\hline Onions & & & & & & & & & & \\
\hline Taste & 4.06 & 0.97 & 4.06 & 0.92 & 4.00 & 0.99 & 4.28 & 0.94 & 3.94 & 0.95 \\
\hline Colour & 3.96 & 1.00 & 3.69 & 0.92 & 3.83 & 1.03 & 4.11 & 0.96 & 4.08 & 0.98 \\
\hline Aroma & 4.02 & 0.98 & 3.94 & 0.94 & 3.95 & 0.95 & 4.12 & 0.93 & 4.06 & 1.10 \\
\hline Dryness & 3.85 & 0.96 & 3.96 & 0.91 & 3.92 & 0.94 & 3.72 & 0.92 & 3.85 & 1.05 \\
\hline $\begin{array}{l}\text { Willing to use } \\
\text { Okra }\end{array}$ & 3.97 & 1.04 & 3.92 & 1.03 & 3.99 & 1.01 & 3.98 & 1.01 & 3.94 & 1.13 \\
\hline Taste & 3.94 & 0.95 & 4.00 & 0.94 & 4.00 & 0.99 & 3.96 & 0.68 & 3.87 & 0.86 \\
\hline Colour & 3.84 & 1.00 & 3.98 & 0.99 & 3.95 & 1.03 & 3.81 & 0.72 & 3.72 & 0.95 \\
\hline Aroma & 3.85 & 0.91 & 3.81 & 0.88 & 3.82 & 0.95 & 3.86 & 0.79 & 3.89 & 0.88 \\
\hline Texture & 3.67 & 0.96 & 3.68 & 1.03 & 3.75 & 0.94 & 3.74 & 0.74 & 3.62 & 0.88 \\
\hline Willing to use & 3.80 & 1.02 & 4.02 & 0.84 & 3.81 & 1.01 & 3.82 & 0.85 & 3.68 & 1.03 \\
\hline
\end{tabular}

\section{Willingness to Use as a Function of Consumers' Perception of Products' Attributes}

Table 2 shows that the overall regression model was significant $(F=38.25 ; p \leq 0.05)$ accounting for $41.6 \%$ (R-square) of the variance. All perception indicators except colour have statistical significance in the consumers' willingness to use the dried onions. Among the different classes, taste and texture have statistical significance $(\beta=0.29 ; p \leq 0.05)$ among young females only. Among Nsukka people, young females are the ones that often cook. Regarding onions, the findings as shown in Table 3, indicate that willingness to use the dried onion among adult females, was not significantly $(\beta=0.17 ; p \geq 0.05)$ influenced by aroma. This can be explained in terms of Daniel Ellis Berlyne's model which states that a set of collative stimulus features have some level of arousal potential. This in turn influences hedonic preferences (Marin, Lampatz, Wandl, and Leder, 2016). One direct positive impact of favourable disposition towards onions dried with LADT is that it will significantly reduce the losses associated with product during the period of glut. Domestic users will, therefore, spend less money and farmers will sale more products. This will improve sustainable agriculture and food security. Ozoude, Igbokoyi, Oluwaseun1, OkeyNdeche and Ukachi (2019), reportd that fungi and bacteria found in onions can affect the health of consumers. Reduced moisture content, drying is capable of preventing microbial activities in stored product (Lianou et al , 2016).

In the case of okra, colour and texture were statistically significant $(p \leq 0.05)$. Patchimaporn, Ilukor, Mockshell, Mujawamariya, Okafor et al. (2018), found that both colour and texture were significant in a customers' willingness to pay for a product. For respondents who were already used to okpo okwuru, the import of colour is heightened by the fact that having been used to dried okra losing its greenness, they 
Creative Commons User License: CC BY-NC-ND

Abstracted by: EBSCOhost, Electronic Journals Service (EJS), Google Scholar, Journal Seek, Scientific Commons,

Food and Agricultural Organization (FAO), CABI and Scopus

http://eoi.citefactor.org/10.11226/v24i3
Journal of Agricultural Extension

Vol. 24 (3) July, 2020

ISSN(e): 24086851; ISSN(Print); 1119944X

http://journal.aesonnigeria.org

http://www.ajol.info/index.php/iae

Email: editorinchief@aesonnigeria.org

are captivated by a drying technology that enabled the colour to be retained. Surprising is the fact that taste was not significant $(p \geq 0.05)$ in the decision to accept or reject the dried okra soup. Fibri and Frost (2019) had suggested that flavour (collative stimulus) is a single most determinant indicator of whether the consumer will continue purchasing a given product. A possible explanation may be linked to the prevailing condition at the time of the study. The study was carried out during the period of COVID-19. It is possible that the fear of contracting the virus through tasting of the product influenced their attitude to tasting the product. If this was the case, it could explain the non-significance of taste in sample consumers' preference for the products.

Table 2: Influence of perception attributes of onion on willingness to use

\begin{tabular}{lccccccccccc}
\hline \multirow{2}{*}{ Characteristics } & \multicolumn{2}{c}{ General } & \multicolumn{3}{c}{ Adult male } & \multicolumn{3}{c}{ Adult female } & \multicolumn{2}{c}{ Young male } & \multicolumn{2}{c}{$\begin{array}{c}\text { Young } \\
\text { female }\end{array}$} \\
& Coeff & SE & Coeff & SE & Coeff & SE & Coeff & SE & Coeff & SE \\
\hline Onions & & & & & & & & & & \\
Intercept & $0.70^{*}$ & 0.28 & 0.73 & 0.67 & 1.50 & 0.56 & 0.53 & 0.49 & 0.32 & 0.52 \\
Taste & $0.16^{*}$ & 0.08 & -0.15 & 0.16 & 0.23 & 0.15 & 0.25 & 0.19 & $0.29^{*}$ & 0.15 \\
Colour & -0.003 & 0.08 & 0.21 & 0.15 & 0.26 & 0.17 & -0.19 & 0.21 & -0.29 & 0.15 \\
Aroma & $0.45^{*}$ & 0.07 & $0.63^{*}$ & 0.14 & 0.17 & 0.16 & $0.64^{*}$ & 0.18 & $0.39^{*}$ & 0.12 \\
Texture & $0.22^{*}$ & 0.07 & 0.14 & 0.14 & -0.02 & 0.15 & 0.13 & 0.16 & $0.53^{*}$ & 0.13 \\
Okra & & & & & & & & & & \\
Intercept & $1.98^{*}$ & 0.32 & $3.25^{*}$ & 0.61 & $1.63^{*}$ & 0.63 & 1.49 & 0.77 & $3.87^{*}$ & 0.48 \\
Taste & 0.09 & 0.09 & 0.05 & 0.18 & 0.18 & 0.17 & 0.14 & 0.18 & 3.72 & 0.14 \\
Colour & $0.24^{*}$ & 0.10 & 0.22 & 0.19 & 0.06 & 0.20 & 0.20 & 0.18 & $3.89^{*}$ & 0.14 \\
Aroma & -0.05 & 0.09 & -0.20 & 0.19 & 0.16 & 0.21 & -0.08 & 0.16 & 3.62 & 0.14 \\
Texture & $0.20^{*}$ & 0.09 & 0.12 & 0.13 & 0.16 & 0.19 & $0.35^{*}$ & 0.17 & 3.68 & 0.14 \\
\hline
\end{tabular}

${ }^{*} \mathrm{P} \leq 0.05$

\section{Conclusion and Recommendations}

There is a general willingness to use the products dried with the load adaptive technology. This is an indication of efficient drying. It also shows that research outputs of Nigerian universities can be used to solve local problems. Accordingly, there is need for university based researchers to focus on the needs and preferences of users. Collaboration with key stakeholders is imperative as it would enable a better appreciation of research outputs.

\section{Acknowledgements}

The authors are grateful to the management and staff of Centre for Lion Gadgets and Technologies for their contribution to the successful development and performance evaluation of the dryer. 
Creative Commons User License: CC BY-NC-ND

Abstracted by: EBSCOhost, Electronic Journals Service (EJS), Google Scholar, Journal Seek, Scientific Commons,

Food and Agricultural Organization (FAO), CABI and Scopus
Journal of Agricultural Extension

Vol. 24 (3) July, 2020

ISSN(e): 24086851; ISSN(Print); 1119944X

http://journal.aesonnigeria.org

http://www.aiol.info/index.php/iae

Email: editorinchief@aesonnigeria.org

\section{References}

Alaba, O.A. Ayanfunke, S.T., K.M. S., Lucky, I. and O.M. O. (2017). Perception of modern processing technology by shea butter processors in Kwara State, Nigeria. Journal of Agricultural extension, 21 (1), 1-14.

Alambaigi, A. and Ahangari, I. (2016). Technology acceptance model (TAM) as a predictor model for explaining agricultural experts behavior in acceptance of ICT. International Journal of Agricultural Management and Development (IJAMAD), Iranian Association of Agricultural Economics, 6(2), 235-247. DOI: 10.22004/ag.econ.262557 .

Ankur, J., S.K. Chandel Dinesh Kumar PalDinesh Kumar Pal (2015). Likert scale: Explored and explained. British Journal of Applied Science \& Technology, 396-403.

Fibri D.L.N. and Frost, M.B. (2019). Consumer perception of original and modernised traditional foods of Indonesia. Appetite,1;133:61-69.

DOI: $\underline{10.1016 / \text { j.appet.2018.10.026 }}$

Hussein J. B, Usman M.A, Filli K.B. (2016). Effect of hybrid solar drying method on the functional and sensory properties of tomato. American Journal of Food Science and Technology, 4 (5), 141-148. DOI:10.12691/ajfst-4 -5

llukor, J. Mockshell, J. Mujawamariya, G. Okafor, C. Bullock R. Nabahungu, N.L.Vanlauwe, B. (2018). What are the key factors influencing consumers' preference and willingness to pay for meat products in Eastern DRC? Food Science and Nutrition, 6(8), 2321-2335. DOI:10.1002/fsn3.813

Isik, I and Yasar M. F. (2015). Effects of brand on consumer preferences: A study in Turkmenistan. Eurasian Journal of Business and Economic, 8(16),139-150. DOI: $\underline{10.17015 / \text { ejbe. } 2015.016 .08}$

Izquierdo-Gil M.A, Barragán V.M.J, Villaluenga G.P.(2020). Estimation of the filament temperature of an incandescent lamp. Journal of Thermal Analysis and Calorimetry, DOI: 10.1007/s10973-020-09609-8.

Jelili, B. H. Ilesanmi J .O, Filli K. B, Sanusi M. S. (2018). Effects of drying methods on the chemical properties of okra (Abelmoschus esculentus L.Moench) Slices. Current Journal of Applied Science and Technology, 26 (6), 1-10.

Latimer, G. W. (2012). Official methods of analysis of AOAC International. $19^{\text {th }}$ edition. Gaithersburg, Md

Lianou A., Panagou E.Z.G. Nychas J.E. (2016). Microbiological Spoilage of Foods and Beverages. In The Stability and Shelf Life of Food (Second Edition) pp.3-42. Woodhead Publishing Series in Food Science, Technology and Nutrition. doi.org/10.1016/B978-0-08-100435-7.00001-0

Ma Meng, Qing-JieSun, Man Li, Ke-Xue Zhu. (2020). Deterioration mechanisms of highmoisture wheat-based food - A review from physicochemical, structural, and molecular perspectives. Food Chemistry, 318, 126495. https://doi.org/10.1016/j.foodchem.2020.126495 
Creative Commons User License: CC BY-NC-ND

Abstracted by: EBSCOhost, Electronic Journals Service (EJS), Google Scholar, Journal Seek, Scientific Commons,

Food and Agricultural Organization (FAO), CABI and Scopus

http://eoi.citefactor.org/10.11226/v24i3
Journal of Agricultural Extension

Vol. 24 (3) July, 2020

ISSN(e): 24086851; ISSN(Print); 1119944X

http://journal.aesonnigeria.org

http://www.ajol.info/index.php/iae

Email: editorinchief@aesonnigeria.org

Marin, M.M. Lampatz, A Wandl, M. and Leder, H. (2016). Berlyne revisited: Evidence for the multifaceted nature of hedonic tone in the appreciation of paintings and music. Frontiers in Human Neuroscience, 10, 536. DOI: 10.3389/fnhum.2016.00536

Md. T.U., Mehedi, H. R. Aurup, R.D. Mr. Badiuzzaman and Md. S.H. (2019). Factors determining consumer preferences for Pangas and Tilapia Fish in Bangladesh: Consumers' perception and consumption habit perspective. Journal of Aquatic Food Product Technology, 28 (4) 438-449. DOI:10.1080/10498850.2019.1597004.

Nwakuba, N.R. , Chukwuezie, O.C., Osuchukwu, L.C. . (2017). Modeling of Drying Process and Energy Consumption of Onion (Ex-gidankwanoSpp.) Slices in a Hybrid Crop Dryer. American Journal of Engineering Research (AJER), 6 (1), 44-55.

Nwakuba N, Okafor V.C. and Okorafor, O.O. (2020) Techno-economic analysis of a hybrid solar-electric dryer, Energy Sources, Part A: Recovery, Utilization, and Environmental Effects. DOI:10.1080/15567036.2020.1782537.

Pollan, M. (2020). The Omnivore's Dilemma: A Natural History of Four Meals - Chapter 16 Summary" eNotes Publishing Ed. eNotes Editorial. eNotes.com, Inc. eNotes.com 24 Jul, 2020.

Qiong O.U. (2017). Brief introduction to perception. Studies in Literature and Language, 15 (4), 18-28 DOI:10.3968/10055.

Ozoude, T. O, Igbokoyi, R. O, Okey-Ndeche N. F and Ukachi E (2019). Evaluation of Pathogenic Microorganisms that Cause Onion Bulb Rots in Selected Markets in Abuja, Nigeria. Microbiology Research Journal International. 29 (4): 1-6, DOI: 10.9734/MRJI/2019/v29i430168

Rasool, S. Gholamreza, C. Mehdi, K. (2017). Drying characteristics and modeling of tomato thin layer drying in combined infrared-hot air dryer. AgricEngInt: CIGR Journal, 19(1), 150-157.

Salvador, L.S. (2014). Determinants of Purchase Decisions and Consumers' Willingness to Pay for Green Products. IAMURE International Journal of Social Sciences,8(1). DOl:10.7718/ijss.v8i1.670

Sam K. (2017). Impact of Energy and Atmosphere. In Handbook of Green Building Design and Construction, Second Edition, pp. 443-571. LEED, BREEAM, and Green Globes.

Seifu, M. Tola, Y.B. Mohammed, A. and Astatkie, T. (2018). Effect of variety and drying temperature on physicochemical quality, functional property, and sensory acceptability of dried onion powder. Food Sci Nutr, 6 (6), 1641-1649. DOI: $10.1002 / \mathrm{fsn} 3.707$.

Sung B, Vanman E, Hartley N (2019). Interest, but not liking, drives consumer preference toward novelty. Australasian Marketing Journal (AMJ) 27(4) 242-248 doi.org/10.1016/j.ausmj.2019.06.003 
Creative Commons User License: CC BY-NC-ND

Abstracted by: EBSCOhost, Electronic Journals Service (EJS),

Google Scholar, Journal Seek, Scientific Commons,

Food and Agricultural Organization (FAO), CABI and Scopus

http://eoi.citefactor.org/10.11226/v24i3
Journal of Agricultural Extension

Vol. 24 (3) July, 2020

ISSN(e): 24086851; ISSN(Print); 1119944X

http://journal.aesonnigeria.org

http://www.ajol.info/index.php/iae

Email: editorinchief@aesonnigeria.org

Symmank, C. Extrinsic and intrinsic food product attributes in consumer and sensory research: literature review and quantification of the findings. Manag $\operatorname{Rev} Q$ 69, 3974 (2019). https://doi.org/10.1007/s11301-018-0146-6

Wolfe J. F. (2020) Forty years after feature integration theory: An introduction to the special issue in honour of the contributions of Anne Treisman. Attention, Perception, \& Psychophysics . 82 (1), 1-6. DOI: 10.3758/s13414-019-01966-3. 